\title{
An investigation on the effect of humidity on the zero signal of a strain gauge measuring system
}

\begin{abstract}
K.M. Khaled ${ }^{1, *}$, G.M. Mahmoud ${ }^{1}$
Edited by

Juan Carlos Salcedo-Reyes

(salcedo.juan@javeriana.edu.co)

1. National Institute for Standards (NIS),

Giza, Egypt, P.O.136, Code 12211.

*khaled_fmmd_nis@yahoo.com

Received: 17-07-2017

Accepted: 30-03-2018

Published on line: 11-05-2018

Citation: Khaled KM, Mahmoud GM. An investigation on the effect of humidity on the strain gauge measuring system,

Universitas Scientiarum, 23 (1): 129-139, 2018. doi: 10.11144/Javeriana.SC23-1.aint

Funding:

Abstract

Humidity is one of the most important ambient factors influencing torque calibration readings. The present study addresses the effects of relative humidity on the readings of reference torque transduction and amplification devices. The results revealed a linear effect of increasing humidity on the readings of a DMP40 torque amplifier and a torque transducer at different temperatures. Furthermore, humidity effects were smaller on the DMP40 amplifier than on the torque transducer, even at different temperatures. The results also showed that the summed effect of humidity changes on torque calibration readings of the amplifier and the torque transducer, when assessed simultaneously, but with each device under different controlled humidity conditions, is greater than the observed effect on the readings when both devices were subjected to humidity changes together. Therefore, it is recommended to test the effect of humidity in setups where these two devices are both under common humidity conditions. This is likely to lower the uncertainty parameter of the obtained torque calibration readings and is a useful consideration for inter-laboratory comparisons and performance testing.
\end{abstract}

N.A.

Electronic supplementary material: N.A.

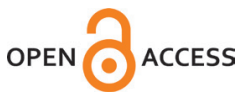

Keywords: Strain gage; torque amplifier; relative humidity; ambient temperature; international system.

\section{Introduction}

Torque measuring systems mainly consist of a torque transducer and a measurement amplifier and may be used inside laboratories or as part of outdoor setups [1]. In either case, knowing the influence of environmental factors such as relative humidity $(\mathrm{RH})$ on the measuring instruments is central to understanding how they perform $[2,3]$. The investigation of the effect of relative humidity on the zero signal of a torque measuring system is relevant to determine how it contributes to the error component and drift of the measuring system readings [4]. This can also explain differences between 
calibration measurements carried out under laboratory and on-site industrial conditions $[5,6]$. The influence of $\mathrm{RH}$ on torque transducers has been considered earlier for inter-laboratory comparisons using a climate-controlled cabinet [7].

Current torque transducers are isolated from the environment such that the effect of RH on the sensing element is minimized [8]. Nonetheless, changes in RH can considerably affect transducer's sensitivity [9]. Thus far, complicated and extensive methodologies have been used to measure humidity effects, but Bruge [8] proposed a simpler approach measure this effect on torque transducers inside calibration laboratories, with fewer resources and at a lower cost. The effect of humidity on the zero signal of a reference torque transducer in known to vary from +3.3 to $-9 \mathrm{nV} / \mathrm{V} \% \mathrm{RH}$, and the influence of humidity on a DMP 40 measurement amplifier, studied at $22^{\circ} \mathrm{C}$, was found to vary from 0.27 to $-1.8 \mathrm{nV} / \mathrm{V} \% \mathrm{RH}[9]$.

In the present work, the effects of relative humidity on the zero signal of a torque transducer and a DMP40 measuring amplifier were studied under increasing RH conditions at four different constant temperatures. The readings of these two devices were taken when subjected to these experimental conditions either individually or together.

Materials and Methods

Apparatus

The following equipment was used in this experimental work:

- A Votsch Stable Climatic Chamber (SCC) (model VC34060,. Germany) with internal dimensions of $0.7 \times 0.8 \times 0.8 \mathrm{~m}$, a temperature range of 283 to $363 \mathrm{~K}$, and an $\mathrm{RH}$ range from $15 \%$ to $95 \%$.

- An HBMDMP40 amplifier (model DMP40S2,. Germany) with the following settings: filter of $0.2 \mathrm{~Hz}$ Bessel, signals reading set to "absolute", the range of measurement was $2.5 \mathrm{mV} / \mathrm{V}$ and the excitation voltage was $5 \mathrm{~V}$. The excitation of the DMP40 amplifier was $220 \mathrm{VAC}$ with $50 \mathrm{~Hz}$.

- An HBM BN100A stable bridge calibration unit (Germany). The DMP40 amplifier and the BN100A were connected with a shielded cable.

- An HBM reference torque transducer (model TN, Germany), with capacity of $1 \mathrm{kN} \cdot \mathrm{m}, \mathrm{IP}: 20$, and an accuracy class of 0.05). 
- Two sets of humidity and temperature ALMEMO sensors (model FHAD3Rx, Germany). One set was placed inside the SCC and the other outside. The sensitivity of each set was of $0.1 \%$ for $\mathrm{RH}$ and $\pm 0.1 \mathrm{~K}$ for temperature.

\section{Experimental procedure}

In the first measurement round, the DMP40 amplifier was placed outside the SCC while the reference torque transducer was placed inside the SCC. The SCC conditions were set to $40 \% \mathrm{RH}$ and temperature of $15{ }^{\circ} \mathrm{C}$ for 12 hours, followed by a programmed RH step-wise increase of $5 \%$ every 4 hours until reaching $80 \% \mathrm{RH}$. This procedure was repeated at $22^{\circ} \mathrm{C}, 31^{\circ} \mathrm{C}$, and $40{ }^{\circ} \mathrm{C}$ with an initial RH of $35 \%$. The following measurement cycle was done as already explained, except that both the DMP40 amplifier and the torque transducer were placed inside the SCC. Finally, the third measurement cycle proceeded as in the previous two, but the DMP40 amplifier was placed inside the chamber and the BN100A unit outside.

The BN100A calibration unit was set to an excitation voltage of $0 \mathrm{mV} / \mathrm{V}$, which is the nearest point to the observed torque transducer zero signal $(0.012130 \mathrm{mV} / \mathrm{V})$. Warm up times for the DMP40 amplifier and the BN100A calibration unit were recorded, and so the time needed for the DMP40's low pass filter to work. All of the experiments were conducted under controlled environmental conditions with stabilities of $\pm 1 \mathrm{~K}$ and $\pm 5 \% \mathrm{RH}$ outside the chamber, and $\pm 0.1 \mathrm{~K}$ and $\pm 0.5 \% \mathrm{RH}$ inside the chamber. All measurements were repeated three times. These measurements were employed to assess the effect of the evaluated experimental conditions on the $\mathrm{RH}$ readings, reflecting the difference between the DMP40 amplifier readings at each $\mathrm{RH}$ value of and the readings taken at initial RH conditions, namely the response difference $(\mathrm{nV} / \mathrm{V})$ for the three measurements.

\section{Results and Discussion}

The effect of humidity on the readings of the torque transducer and the DMP40 amplifier was proportional to the increase in temperature and humidity conditions to which these devices were subjected (individually and together) during the experiments (Fig. 1a - d). Throughout the four tested temperatures $\left(15^{\circ} \mathrm{C}, 22^{\circ} \mathrm{C}, 31^{\circ} \mathrm{C}\right.$, and $\left.40^{\circ} \mathrm{C}\right)$, the readings of the DMP 40 amplifier, when exposed to experimental conditions alone, were the least affected by the controlled RH increase, whereas the readings of the transducer, when exposed to experimental conditions alone, were affected by $\mathrm{RH}$ with reading values increasing in a linear fashion. Interestingly, the effect of increasing $\mathrm{RH}$ was less pronounced on the two devices tested together than on the transducer alone. 
a)

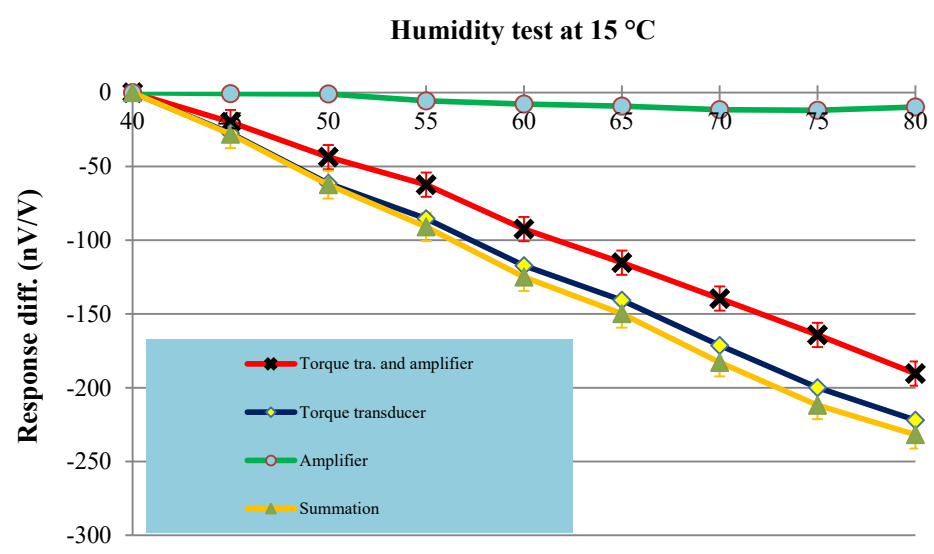

Humidity (\% RH) b)

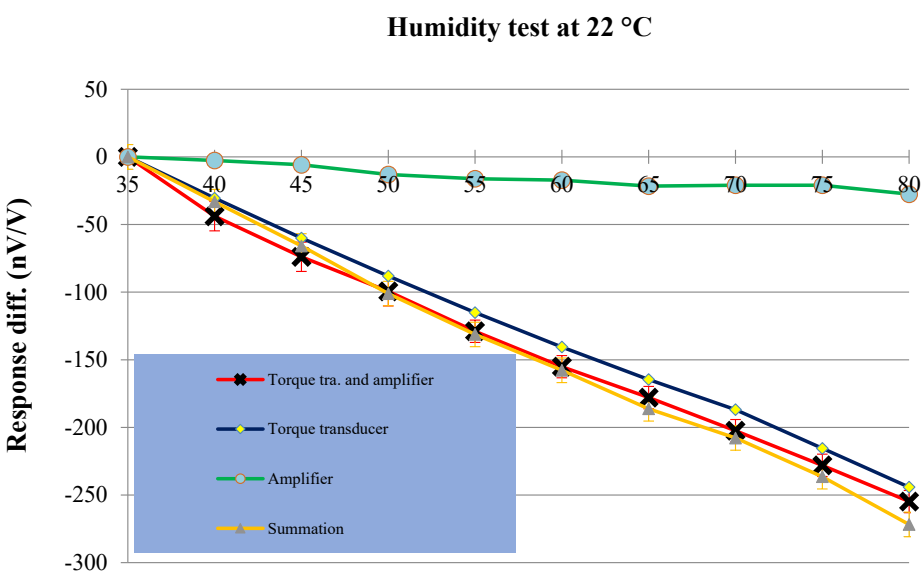

Humidity (\% RH)

d)

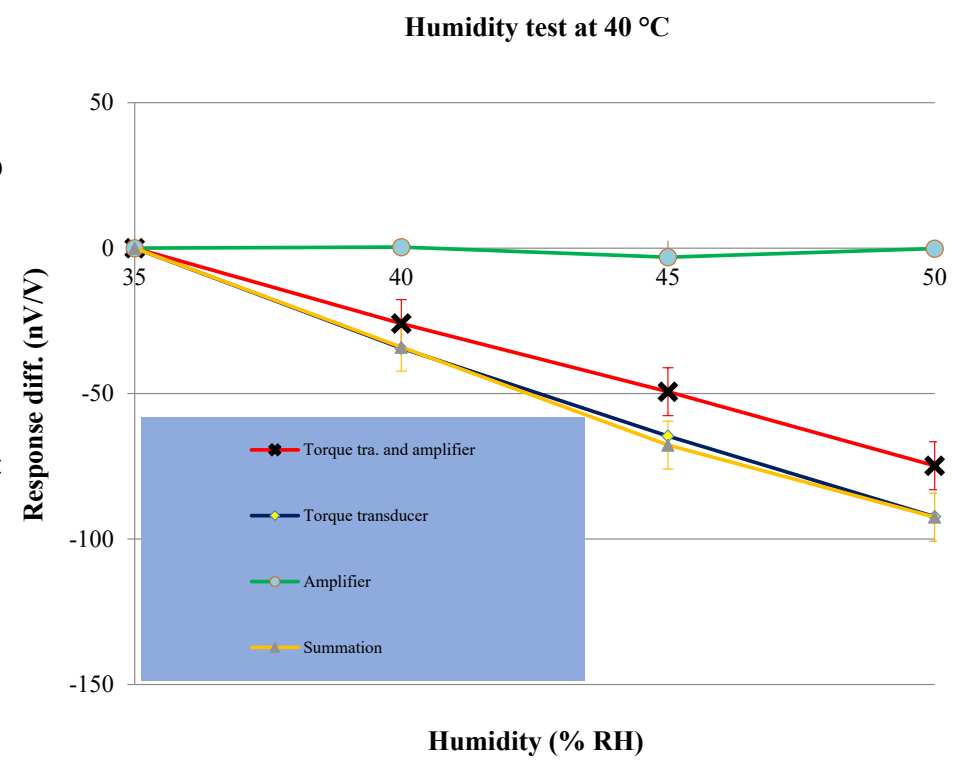

Humidity (\% RH) c)

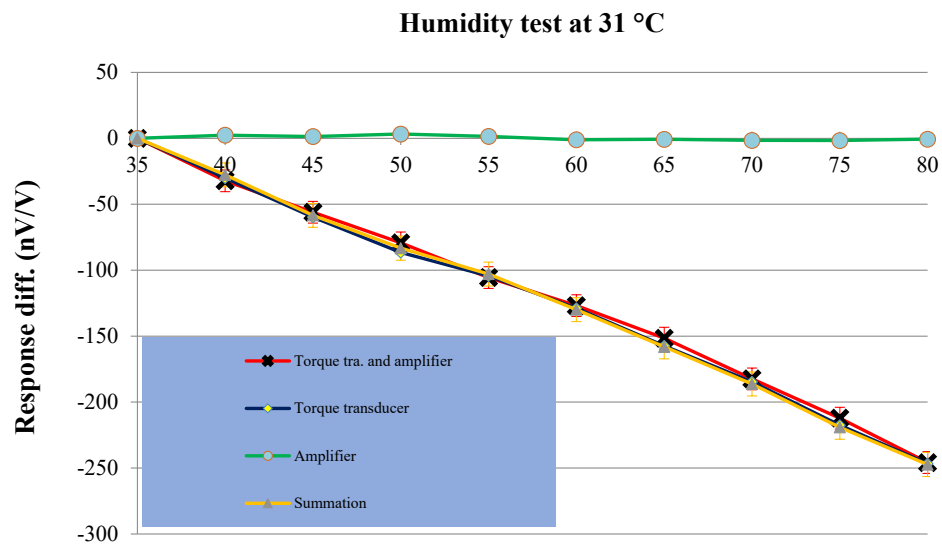

Humidity (\% RH)

Figure 1. Effect of controlled, changing relative humidity conditions on the readings of a DMP40 amplifier and a torque transducer when subjected to experimental conditions separately and together at temperatures of a) $15^{\circ} \mathrm{C}$; b) $22{ }^{\circ} \mathrm{C}$; c) $31^{\circ} \mathrm{C}$; and d) $40^{\circ} \mathrm{C}$.

Moreover, the summed effects of each treatment on the readings of the DMP40 amplifier and the transducer were slightly more pronounced than those of the transducer alone. However, temperature played also a role in eliciting this effect response (Fig. 1c). For instance, at $31^{\circ} \mathrm{C}$ the differences between combined effects of the transducer and amplifier (subjected together to experimental conditions) and the sum of independent effects of the two devices were indistinguishable. This is likely due an influence of $\mathrm{RH}$ on 
the amplifier smaller than the influence of $\mathrm{RH}$ on the transducer itself. The measurements at $40{ }^{\circ} \mathrm{C}$ shown in Fig. $1 \mathrm{~d}$ were carried out with a maximum $\mathrm{RH}$ of $50 \%$ since the transducer's specification state that at a temperature of $40{ }^{\circ} \mathrm{C}, \mathrm{RH}$ must not exceed $50 \%$.

The $\mathrm{x}$-axis is the \% RH and the $\mathrm{y}$-axis is the effect of the evaluated experimental conditions on the $\mathrm{RH}$ reading, expressed as the difference between the DMP40 amplifier readings at each $\mathrm{RH}$ value of and the reading taken at initial $\mathrm{RH}$ conditions for the three measurements. Inset legend: i) torque transducer and DMP40 amplifier both inside the chamber; ii) Torque transducer inside the chamber and DMP40 amplifier outside; and iii) torque transducer outside the chamber and DMP40 amplifier inside.

The following simple linear relationship can be used to predict the influence of increasing humidity at a given ambient temperature at only one humidity step change.

$$
R=K \times H
$$

Where $\mathrm{R}$ is the amplifier/transducer response change in $(\mathrm{nV} / \mathrm{V}), \mathrm{K}$ is the amplifier/transducer humidity coefficient in $(\mathrm{nV} / \mathrm{V}) /(\% \mathrm{RH})$ and $\mathrm{H}$ is the humidity change in (\% RH).As shown in Table 1 , the humidity coefficient $\mathrm{K}(\mathrm{nV} / \mathrm{V}) /(\% \mathrm{RH})$ varies from -5.5 to -6 for the transducer, from 0 to -0.6 for the amplifier, and from -4.8 to -5.6 for the transducer and amplifier together. The values provided in Table 1 are useful for those who employ similar transducers and amplifiers, individually or together, in work setups where humidity is not controlled and during long-term measurements or performance testing where surrounding humidity differs among setups.

Most of the added effects of RH on the measurements of the DMP40 amplifier and the torque transducer were slightly greater than the effects on both devices when subjected to humidity changes together (Table 2). This is likely due to humidity on the connecting wires. Therefore, it is recommended to assess humidity effects on the amplifier and the torque transducer together, thus minimizing one the sources of uncertainty in the measurements. Moreover, this difference could be negligible in most industrial applications, such as in the calibration of torque testing machines, within their uncertainties, but it could also be significant in high accuracy measurements such as international comparisons, performance test or research activities. 
Table 1. Humidity coefficient $(\mathrm{K})$ values for the transducer alone, the amplifier alone, and both devices subjected to controlled humidity changes across different temperatures.

\section{Temperature}

$\left({ }^{\circ} \mathrm{C}\right)$

\section{Humidity coefficient $\mathrm{K}(\mathrm{nV} / \mathrm{V}) /(\% \mathrm{RH})$}

Transducer Amplifier
Transducer and amplifier

\begin{tabular}{|cccc}
\hline 15 & -5.6 & -0.3 & -4.8 \\
\hline 22 & -5.5 & -0.6 & -5.6 \\
\hline 31 & -5.4 & -0.0 & -5.4 \\
\hline 40 & -6.0 & -0.1 & -5.0 \\
\hline
\end{tabular}

The humidity effect is assumed to be the result of a combination of mechanical and electrical changes. Humidity changes can affect the mechanical properties of the both the torque transducer's strain gauges and the adhesive layers which are used to bond these strain gauges with the elastic member of the transducer. This effect is positively related to the change of the sensitivity of the strain gauge bridges as well as to the time constants of their response. The change of humidity can also affect the electrical charges of the wiring inside the strain gauge system, the transducer, and the measuring amplifier.

Finally, the resulting humidity influence will act exponentially, but not immediately, on the strain gage bridge. From a practical viewpoint, the measuring amplifier is often used with different transducers. Therefore, this investigation could reflect advantageously on torque and force measurements. 
Table 2. Relative differences between the summation and the experimental results of the DMP40 amplifier and torque transducer when subjected to humidity change separately and together.

Humidity $(\% \mathrm{RH})$

$\begin{array}{lllllllll}40 & 45 & 50 & 55 & 60 & 65 & 70 & 75 & 80\end{array}$

Temperature

$\left({ }^{\circ} \mathrm{C}\right)$

Relative diff. between the summation and the experimental $(\%)$

\begin{tabular}{llllllllll}
\hline 15 & - & 41 & 43 & 46 & 35 & 30 & 31 & 29 & 22 \\
\hline 22 & -24 & -11 & 2 & 2 & 2 & 5 & 3 & 4 & 7 \\
\hline 31 & -14 & 4 & 5 & -3 & 2 & 4 & 2 & 3 & 1 \\
\hline 40 & 31 & 37 & 24 & - & & & & & \\
\hline
\end{tabular}

\section{Conclusions}

From the current experimental work, it can be concluded that (i) the influence of relative humidity on the measurements amplifiers is small, compared to that of torque transducer even at different temperatures. (ii) The summed influence of RH on the amplifier and the reference torque transducer is equal to, or in some cases slightly greater than, the RH effect observed when both devices are subjected to humidity changes together. Therefore, it is recommended to test the humidity effect on the measuring amplifier and torque transducer together. This would prevent from inflating the effect values unnecessarily, thus lowering the uncertainty parameter which can be critical in inter-laboratory comparisons and performance testing. (iii) The humidity coefficient $\mathrm{K}(\mathrm{nV} / \mathrm{V}) /(\% \mathrm{rH})$ varies from -5.5 to -6 for the transducer, 0 to -0.6 for the amplifier, and -4.8 to -5.6 for transducer and amplifier together, respectively.

\section{Conflict of interest}

The authors have no conflict of interest to declare.

\section{Acknowledgments}

The authors are thankful to the anonymous reviewers and editor for having substantially improved this manuscript with their comments and suggestions. 


\section{References}

[1] Rainer Schicker and Georg Wegener, "Measuring Torque Correctly", HBM publish, Germany - 2002, ISBN 3-00-008945-4.

[2] N. Whitehead, A. Cheshmehdoost, A. Verrall, and B. E. Jones, "Torque sensor employing a mechanical resonator", Sensors and Actuators A, 60, pp. 29-31, 1997.

https://doi.org/10.1016/S0924-4247(96)01415-X

[3] K. M. Khaled, G. Aggag, A. E. Abuelezz, M. G. Elsherbiny "The influence of misalignment on the uncertainty of vertical torque calibration machine" MAPAN-Journal of Metrology Society of India 06/2011; 26(2):153-157.

doi: 10.1007/s12647-011-0015-4

[4] K. Ohgushi, T. Ota, K. Ueda and E. Furuta, "Design and Development of the $20 \mathrm{kN} \cdot \mathrm{m}$ Deadweight Torque Standard Machine", VDIBerichte, 1685, pp. 327-332, 2002.

[5] Khaled Abdelaziz Mohamed, "Design, Construction and Performance Evaluation of Torque Standard Machine", Master Thesis, Faculty of Engineering, Cairo University, July 2010.

doi: 10.13140/RG.2.1.4384.8569

[6] R.A. Mitchell, S.M. Backer, "Characterization of the creep response of load cell”, VDI-Berichte, Volume 312, pp. 43-48, 1978.

[7] D. Röske, "Final report on the torque key comparison CCM.T-K1. Measurand torque: $0 \mathrm{~N} \cdot \mathrm{m}, 500 \mathrm{~N} \cdot \mathrm{m}, 1000 \mathrm{~N} \cdot \mathrm{m}$ ”, Metrologia, Volume 46, Tech. Suppl. 07006, published 2015.

http://iopscience.iop.org/article/10.1088/0026-1394/46/1A/07002/meta

[8] Andreas Brüge, "Simplified measurements of the humidity coefficient of torque transducers in calibration laboratories", Acta IMEKO, vol. 3, no. 2, article 9, June 2014, identifier: IMEKOACTA-03 (2014)-02-09

https://acta.imeko.org/index.php/acta-imeko/article/view/IMEKOACTA-03\%20\%282014\%29-02-09/257

[9] K.M. Khaled, D. Röske, A.E. Abuelezz and M.G. Elsherbiny, "Humidity and temperature effects on torque transducers, bridge calibration unit and amplifiers", Measurement 74 31-42, 2015.

doi: 10.1016/j.measurement.2015.07.007 


\section{Análisis del efecto de la humedad en las lecturas de referencia de un sistema para medición de torque}

Resumen. La humedad es uno de los factores ambientales que más influyen sobre las lecturas de calibración de mediciones de torque. En este trabajo se estudiaron los efectos de la variación de la humedad relativa sobre las lecturas de aparatos de referencia para transducción y amplificación de torque. Los resultados mostraron una relación lineal y positiva entre el aumento de la humedad relativa y el componente de error de las mediciones de referencia de un transductor y un amplificador de torque DMP40 bajo cuatro temperaturas distintas. Sin importar la temperatura, las mediciones del transductor de torque fueron más susceptibles de ser afectadas por la humidad relativa que las del amplificador DMP40. Se observó también que la suma de los efectos de la humedad relativa en las lecturas de referencia del amplificador y el transductor fueron mayores cuando ambos aparatos fueron operados bajo condiciones de humedad relativa y temperatura distintas (i.e. el amplificador se encontraba en una cámara climática controlada y el transductor fuera de ella, y viceversa) que cuando ambos aparatos fueron operados bajo las mismas condiciones ambientales (i.e. ambos dentro de la cámara climática controlada). En consecuencia, se recomienda llevar a cabo evaluaciones de la humedad en espacios donde ambos aparatos estén bajo las mismas condiciones de temperatura y humedad relativa. Esto puede reducir el componente de incertidumbre de lecturas de calibración de torque y es un factor a considerar al llevar a cabo comparaciones entre laboratorios y tests de desempeño en aplicaciones industriales.

Palabras clave: sistema extensométrico; amplificador de torque; humedad relativa; temperatura ambiental. 


\section{Investigação do efeito da umidade nas leituras de referência de um sistema para medição de torque}

Resumo. A umidade é um dos fatores ambientais que mais influenciam as leituras de calibração de medições de torque. O presente estudo analisou os efeitos da umidade relativa sobre as leituras de equipamentos de referência para transdução e amplificação de torque. Os resultados mostraram um efeito linear do aumento da umidade relativa na medição de referência de um transdutor e um amplificador de torque DMP40 em quatro temperaturas diferentes. Adicionalmente, os efeitos da umidade foram menores no amplificador DMP40 do que no transdutor de torque em todas as quatro temperaturas. Os resultados também mostraram que a soma dos efeitos da umidade relativa nas leituras de referência do amplificador e do transdutor foram maiores quando ambos equipamentos foram operados em condições de umidade relativa e temperatura distintas (p.e. o amplificador se encontrava em uma câmara climática controlada e o transdutor fora da câmara, e vice-versa) do que quando ambos equipamentos eram operados nas mesmas condições ambientais (p.e. ambos dentro da câmara climática controlada). Assim sendo, se recomenda avaliar o efeito da umidade em espaços onde ambos equipamentos estejam expostos a mesmas condições de temperatura e umidade relativa. Esso pode reduzir o parâmetro de incerteza das leituras de calibração de torque e é um fator a ser considerado ao realizar comparações entre laboratórios e testes de desempenho em aplicações industriais.

Palavras-chave: calibre de tensão; amplificador de torque; umidade relativa; temperatura ambiente. 


\section{K.M. Khaled}

Dr. Khaled is a researcher at National Institute for Standards in the fields of force, torque, hardness, and mechanical testing. With a BSc title in Mechatronics engineering, MSc in Mechanical engineering, and a Ph.D. in Mechanical engineering. He have 13 years of work experience in calibration, accreditation, and conformity assessment.

\section{G.M. Mahmoud}

Dr. Mahmoud is a researcher at National Institute for Standards in the fields of force, torque, hardness, and mechanical testing. With a BSc in Industrial engineering, MSc in Mechanical engineering, and a Ph.D. in Mechanical engineering. He have 13 years of work experience in calibration, accreditation, and auditing. 